\title{
Detection of microfilaria infection in horses in Mosul city
}

\author{
E. G. Suleiman ${ }^{1}$, S. S. Aghwan ${ }^{1}$ and O. M. Al- Iraqi ${ }^{2}$ \\ ${ }^{1}$ Department of Microbiology, ${ }^{2}$ Department of Internal and Preventive Medicine, College of Veterinary Medicine, University \\ of Mosul, Mosul, Iraq
}

\begin{abstract}
The study was performed on 78 horses in Mosul city were examined from April 2007 to September 2009 for the detection of microfilaria in the blood Twenty five clinically normal animals served as control. The percentage of the infection with microfilaria of Setaria spp was $30.76 \%$ they were sheathed, measuring $204-228 \mu \mathrm{m}$ within a mean of $218.4 \mu \mathrm{m}$ in length and 4.5-4.8 $\mathrm{m} \mu$ within a mean of $4.62 \mu \mathrm{m}$ in width. A high percentage of infection was reported in females $54.28 \%$ ) with significant differences from that of males. No significant differences were noticed between the healthy and these showing some clinical sings or between these treated with ivermectin or non treated. Haematological changes indicated decrease in level of hemoglobin concentration packed cell volume whereas there was significant increase $(\mathrm{P} \leq 0.05)$ in total leukocytes count, anemia was macrocytic hypochromic type.
\end{abstract}

Keywords: Microfilaria; Setaria spp; Ivermectin; Equine. Available online at http://www.vetmedmosul.org/ijvs

$$
\begin{aligned}
& \text { تحديد الخمج باليرقات الخيطية الاقيقة في الخيول في مدينة الموصل }
\end{aligned}
$$

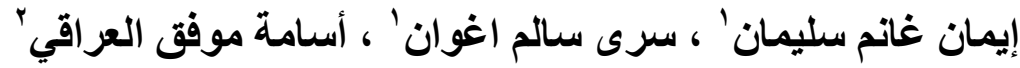

$$
\begin{aligned}
& \text { 'فرع الأحياء الججرية، 'فرع الطب الباطني والوقائي، كلية الطب البيطري، جامعة الموصل، الموصل، العراق }
\end{aligned}
$$

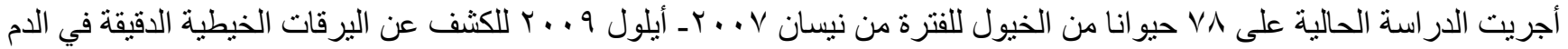

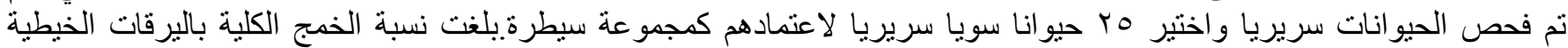

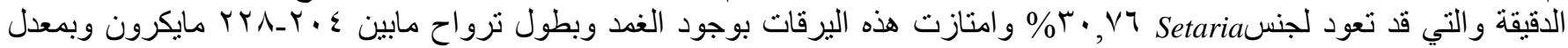

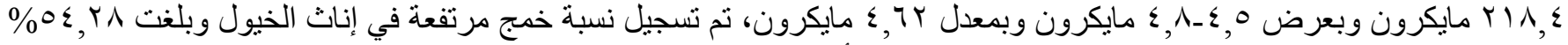

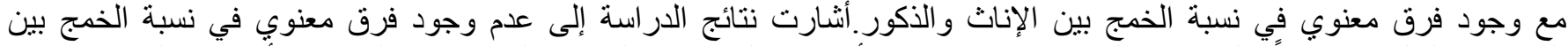

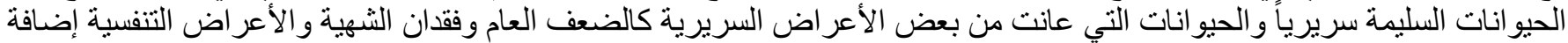

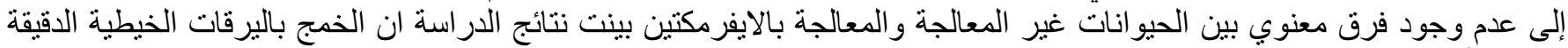

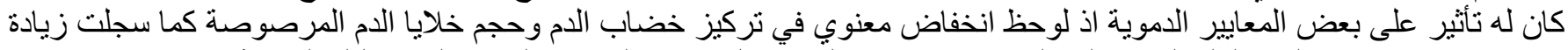

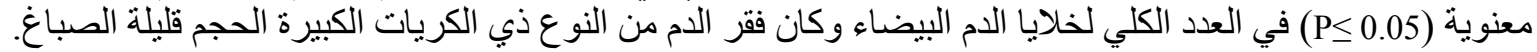

\section{Introduction}

Filarioid nematodes are known to occur among domestic animals all over the world (1). In equines, there are many species of nematodes in order: Spirurida, Superfamily: Filaroidae, Family, Filariidae, Onchocerchidae and these families include many genera and species that infect equines like: Onchocerca cervicalis,
O. gutturosa, O. reticulata, Setaria equina and Parafilaria multipapillosa $(2,3)$, generally, species of Onchocerca are medium-sized filarioides which usually inhabit subcutaneous tissues ligaments and aponeuroses of large mammals whereas species of Setaria are found in the abdominal cavities of artiodactyls, the filariids (Parafilaria and Stenphanofilaria) are small to medium-sized subcutaneous parasites of certain mammals. All filarioid 
nematodes produce larvae (microfilariae, $\mathrm{mf}$ ) in the skin (Onchocerca spp., Parafilaria spp., and Stenphanofilaria spp.) or blood circulation (Setaria spp.) of the host where they are available to the haematophagus insects which operate as intermediate hosts and active vectors for the parasites $(1,4)$.

In their normal definitive host most species of Filarioid nematode, are often very well adapted and they are well tolerated (5). The studies are reported that high percentage of infection with microfilariae in horses in different word (6-8). Horses are commonly infected with Setaria spp. in Asia, Europe and America (9-11).

Cutaneous Onchocercosis is common on horses in the United State of America. In fact many surveys carried out there showed that about $20-100 \%$ of horses are carried Onchocerca microfilariae (12). The species Setaria equina is a common parasite of equines in all parts of the world, the infection rate may be high and up to $50 \%$ of horses may be infected in endemic areas (13). In Iraq Yousif et al., (14) diagnosed for the first time presence of microfilaria in horses in Mosul city and the species of nematode related to the genus Setaria equina, also two species of microfilariae were observed in blood of horses in Mosul city, one of them was identified to be Setaria equina (15). The aim of this study was to determine the prevalence of microfilariae in horses in Mosul city.

\section{Materials and methods}

A total of 78 horses from both sexes and of 3-10 years of age were examined in Teaching Veterinary Hospital (College of Veterinary Medicine, University of Mosul and from other regions in Mosul city during the period from April 2007 to September 2009 for the detection of microfilariae infection from 78 horses clinically normal horses $(\mathrm{n}=25)$ were served as a control Blood samples were taken from these animals and from those (78) horses showed different clinical sings (weakness depression and variable appetite). From the 78 horses 65 were not treated with ivermectin while the remaining 13 were with history of ivermectin treatment $(0.2 \mathrm{mg} / \mathrm{kg}$ orally) Blood samples were collected from jugular vein in EDTA tubes, Knott's technique described by (16) was used for detection of microfilaria. The diagnosis of microfilariae based on morphometric study Species of microfilaria were identified according to $(5,13)$. Hematological examination was done by using (Automatic Full Digital Cell Counter Beckman USA) to get the total red blood cells, hemoglobin concentration $(\mathrm{Hb})$, packed cell volume $(\mathrm{PCV})$, mean corpuscular volume (MCV), mean corpuscular hemoglobin concentration (MCHC) and total leukocytes (17). Statistical analysis was performed by using chi- square and t-test (18).

\section{Results}

The number of positive samples was 24 with a total percentage of $30.76 \%$. From Table (1) it is evident that there were a significant $\mathrm{P}<0.05$ differences in percentage of infection between males (11.62\%) and females (54.28\%). In Table (2) microfilariae diagnosed in 20 blood samples which were collected from healthy animals with a percentage of $28.57 \%$ while the percentage of infection with microfilariae in animals showed some clinical sings such as weakness, respiratory sings depression and variable appetite was $50 \%$ no significant differences were noticed between healthy and those showing some clinical sings. In Table (3) there was no significant difference between treated and non treated horses with ivermectin and 27.69\% of non treated horses were positive for microfilariae while $46.15 \%$ of treated horses were positive for microfilariae. The hematological picture elucidated in Table (4) reveals that there was a significant $(\mathrm{P} \leq 0.05)$ reduction in HB PCV MCHC, with significant $(\mathrm{P} \leq 0.05)$ increase $\mathrm{MCH}$ and total WBCs in infected horses compared with control.

Table 1: The percentage of infection with microfilariae according to sex.

\begin{tabular}{lccc}
\hline $\begin{array}{l}\text { Sex of } \\
\text { animals }\end{array}$ & $\begin{array}{c}\text { No. of the } \\
\text { examined } \\
\text { animals }\end{array}$ & $\begin{array}{c}\text { No. of the } \\
\text { positive } \\
\text { animals }\end{array}$ & $\%$ \\
\hline Males & 43 & 5 & $11.62 \mathrm{a}$ \\
Females & 35 & 19 & $54.28 \mathrm{~b}$ \\
\hline Total & 78 & 24 & 30.76 \\
\hline
\end{tabular}

Groups with different letters have significant differences of $\mathrm{P} \leq 0.01$.

Table 2: Percentage of Microfilariae infection in horses showed some clinical sings and horses clinically normal.

\begin{tabular}{lccc}
\hline $\begin{array}{l}\text { Groups of } \\
\text { horses }\end{array}$ & $\begin{array}{c}\text { No. of the } \\
\text { examined } \\
\text { horses }\end{array}$ & $\begin{array}{c}\text { No. of the } \\
\text { positive } \\
\text { horses }\end{array}$ & $\begin{array}{c}\% \text { of } \\
\text { infection }\end{array}$ \\
\hline $\begin{array}{l}\text { Horses } \\
\text { clinically } \\
\text { normal }\end{array}$ & 70 & 20 & $28.57 \mathrm{a}$ \\
$\begin{array}{l}\text { Horses with } \\
\text { some clinical } \\
\text { sings }\end{array}$ & 8 & 4 & $50 \mathrm{a}$ \\
\hline Total & 78 & 24 & 30.76 \\
\hline
\end{tabular}

Groups with same letters have non-significant differences at $\mathrm{P} \geq 0.01$.

Examination of blood by Knott's technique revealed the presence of microfilariae which may be related to species of Setaria equina and the identified of microfilariae based on 
morphological characteristics and the site of infection Microfilariae ranged between 204-228 $\mu \mathrm{m}$ within a mean of $218.4 \mu \mathrm{m}$ and the width ranged between 4.5-4.8 $\mu \mathrm{m}$ within a mean of $4.62 \mu \mathrm{m}$, and these microfilariae are sheathed and the number of microfilariae which were presence in blood film ranged between 1-2 larvae (Fig. 1).

Table 3: Percentage of Microfilariae infection between treated and non treated horses.

\begin{tabular}{lccc}
\hline $\begin{array}{l}\text { Groups of } \\
\text { horses }\end{array}$ & $\begin{array}{c}\text { No. of the } \\
\text { examined } \\
\text { horses }\end{array}$ & $\begin{array}{c}\text { No. of the } \\
\text { positive } \\
\text { horses }\end{array}$ & $\%$ \\
\hline $\begin{array}{l}\text { Non treated } \\
\text { horses }\end{array}$ & 65 & 18 & $27.69 \mathrm{a}$ \\
$\begin{array}{l}\text { Treated } \\
\text { horses }\end{array}$ & 13 & 6 & $46.15 \mathrm{a}$ \\
\hline Total & 78 & 24 & 30.76 \\
\hline
\end{tabular}

Groups with same letters have non-significant differences at $\mathrm{P} \geq 0.01$.

Table 4: Blood parameters of infected group with microfilariae and control group.

\begin{tabular}{lcc}
\hline \multirow{2}{*}{ Parameters } & Control & Infected \\
\cline { 2 - 3 } & Mean \pm S.E. & Mean \pm S.E. \\
\hline RBC x $10^{6}$ microliter & $7.44 \pm 0.72$ & $7.34 \pm 0.31$ \\
Hbg $/ 100 \mathrm{ml}$ & $13.27 \pm 1.79$ & $12.44 \pm 1.57^{*}$ \\
PCV \% & $35.53 \pm 3.78$ & $33.00 \pm 5.21^{*}$ \\
MCV \% & $16.64 \pm 1.39$ & $17.96 \pm 1.07^{*}$ \\
MCHC g/100 ml & $10.67 \pm 2.14$ & $10.04 \pm 2.75^{*}$ \\
WBC x $10^{3}$ microliter & $51.38 \pm 1.37$ & $51.96 \pm 1.49^{*}$ \\
\hline
\end{tabular}

${ }^{*} \mathrm{P} \leq 0.05$.

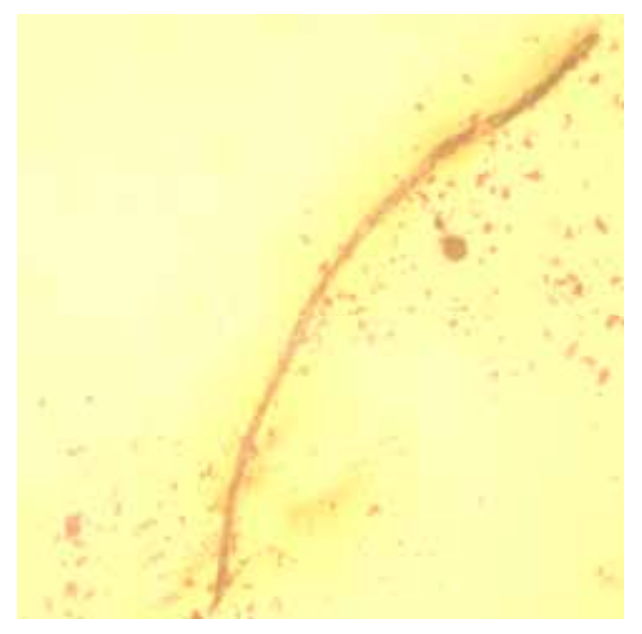

Fig. 1: Microfilaria of Setaria spp in blood of horse by knott's technique $40 \mathrm{X}$ by using digital camera.

\section{Discussion}

In this study, the total percentage of infection with microfilariae in blood samples of horses was $30.76 \%$ the species of microfilariae which were diagnosed may be $\mathrm{mf}$ of Setaria equina these results were agreement with a study which performed in Mosul city by (15) who referred the presence $\mathrm{mf}$ in 10 out of 50 blood sample of horses and $\mathrm{mf}$ of Setaria equina diagnosed in 5 horses In other studies carried out in different parts of the world indicated that the high prevalence of microfilariae in horses in Asia, Europe and America (9-11), also (13) showed that the infection rate with Setaria equina may be high and up to $50 \%$ of horses may be infected in endemic area, while in a study done in Finland demonstrated through the examination of blood and skin that the horses and sheep may be free from Filaroid nematodes (5).

The high rate of infection with microfilariae appeared in females $(54.28 \%)$ with a significant difference between males and females, was in agreement with $(6,19,20)$ while (7) referred that the infection was more common in older horses and occurred in both sexes equally. From the Table 2 there was no significant difference in the percentage of infection between animals apparently healthy and animals showed some different clinical sings Infections with helminthes often cause chronic disease with a wide spectrum of clinical manifestations, ranging from a symptomatic to severe pathology (21). Radosititis et al., (22) showed a high incidence of $S$. equina infestation has been observed in horses in Europe and although no clinical illness was observed there was evidence of recent peritonitis at slaughter.

Setaria equina is found in the peritoneal cavity and sometimes in the scrotum, it has also been recorded from the pleural cavity lungs and eyes of the horses, with no clinical sings when worms in their normal sites, but when nervous tissues involved there is locomotor disturbances of the hind limbs and if the parasites are high in the spinal canal there may be paraplegia $(13,23)$ Abu-Elmagd and Ahmed (24) showed that the Setaria equina could affect on donkey eye with serious lesions such as continuous lacrimation and ulcerative dermatitis.

Their was no significant differences between animals non-treated with ivermectin and animals had history of treatment with ivermectin the percentage of infection with microfilariae in treated animals was $46.15 \%$ and the blood of these animals examined after 7-14 days post treatment Eub-Elmagd etal., (25) revealed that the treatment with ivermectin (Ivomc-MSD) by the injection $1.0 \mathrm{ml} / 50 \mathrm{~kg}$ B.W of one dose subcutaneously gave good results after 7 days post treatment This drug was effective on adults and microfilaria of S.equina in horses suffering from the enlarged scrotum the efficacy of ivermectin was 
demonstrated through disappearance of those clinical sings and microfilaria

Hematological parameters showed relatively significant decrease in the level of hemoglobin and packed cell volume in infected horses as compared to control groups these results were agreement studies carried out on cattle and dogs by others (26-29) and this might be due to rapid disintegration of erythrocytes causing hemolysis (27). Anemia was macrocytic hypchromic type due to significant increase in the mean corpuscular volume and reduction in the mean corpuscular hemoglobin concentration. Sharma and Pachauri (30) revealed that the filarial worms meet their nutrients requirement from the host tissues and fluids and in situ transfer of nutrients from the host tissues to the body of parasites causes various deficiency symptoms including anemia depending on the worm load of the host. The significant increase in WBC was agreement with (2629) in cattle and dogs and (29) showed that the rise in the total leukocytes count (TLC) was indicative of chronic parasitemia and the rise in the eosinophil count was coupled with the microfilariaemia which indicated body response of defense mechanism through the parasitical action of eosinophil, the degree of lymphocytosis occurred depend upon the intensity of parasitemia.

About all of these results, the differences in the prevalence of the infection could be attributed to many factors such as the number of blood samples examined, seasons of the study (the prevalence is higher in wormer countries, where there is long seasonal activity of the mosquitoes vectors), animals factors (sex, age, breed, etc.), farm management and the time of blood taken because the microfilaria characterized by having the diurnal or nocturnal periodicity and the number of microfilariae are present in greatest numbers in capillary blood between 8 and $12 \mathrm{pm}$ at lower temperatures and at higher barometric pressures, all of those factors would probably increase the chances of spread by insect vectors $(13,19,20,22,23)$.

\section{References}

1. Anderson RC. Nematoda Parasites of vertebrates, their development and transmission. The superfamily filaroidea. New York : CABI Publishing; 2000 p.467-529.

2. Kassai T. Veterinary helminthology. $1^{\text {st }}$ ed. Great Britain, Bath Press, Somerset; 1999 p.119-133.

3. Drudye JH, Lyons ET. Internal parasites of equids with Emphasis on treatment and control USA. Hoechst- Russell Agri Vet Company;1989.p.15-17.

4. Kolte SS, Satarker RN, Mane PM. Microfilaria concomitant with metastasis deposits of adenocarcinoma in lymph node fine needle aspiration cytology : A chance finding. J Cytol [Serial online] 2010 Available from : http://www.ycytol.org/text.asp.

5. Solisma M, Laaksonen S, Nylund M, Pitkanen E, Airakorpi R, Oksanen A. Filarioid nematodes in cattle, sheep and horses in Finland Acta Vet Scand. 2008 ; 50(1): 20-50.

6. Collins RC. Onchoceriasis of horses in South Eastern Louisiana. J Parasitol. 1973 ; 59(59): 1016-1920.
7. Staunard AA and Cello RM. Onchocerca cervicalis infection in horses from western United States. Am J Vet Res. 1975 ; 36(11): 1029-1031.

8. Lloyd S and Soulsby EJL. Survey for infection with Onchocerca cervicalis in horses in Eastern United States. Am J Vet Res. 1978 ; 39(1): 1962-1969.

9. Siddiqui AA, Sharma SP, Kumar M. Prevalence of Setaria infection in buffaloes and horses. Indian J Anim Sci. 1994 ; 66: 243-245.

10. Buchwalder R, Schuster R. Finding Setaria equina in horses (abstract). Angew Parasitol. 1989; 30: 127-130. (Pubmed).

11. Coleman SU, Klei TR, French DD. Prevalence (Nematode : Onchocercidae) in Southeastern Louisiana horses. J Parasitol. 1985 ; 71: $512-513$

12. Lyons ET, Swerczek TW, Tolliver SC, Bair HD, Drudge JH, Ennis LE. Prevalence of selected species of internal parasites in equids at necropsy in central Kentucky (995-1999). Vet Parasitol. 2000 ; 92: 5162.

13. Soulsby EJL. Helminths, arthropods and protozoa of domesticated animals. $7^{\text {th }}$ ed. Philadelphia, Bailliere Tindall, London; 1986. p.306317.

14. Yousif YA, Hayattee ZG, Saleen AN, Joshi HC. Haemato-biochemical changes in microfilariae affected horses under field condition. J Vet Parasit. 1990 ; 4: 55-58.

15. Alousi TI, Arslan SH, Zangana IK. Study of some parasitic infections in horses in Mosul region. Iraqi J Vet Sci. 1994; 2(2): 85-91.

16. Hendrix CM. Diagnostic Veterinary Parasitology. $2^{\text {nd }}$ ed. Mosby Inc. United States of America; 1998 p. 269-271.

17. Meyer DJ and Harvy JW. Veterinary Laboratory Medicine. $2^{\text {nd }}$ ed. W.B. Saunders Co ; 1998 p.157-199.

18. Bruning LJ, Kintz BL. Computational handbook statistics, $2^{\text {nd }}$ ed. Scott Foresman and Company, England;1977. p. 233-237.

19. Butty ET. Diagnostic study of microfilariae in blood samples of cattle in Mosul city- Iraq. Iraqi J Vet Sci. 2006; 20(2): 219-224.

20. Ottley ML, Moorhouse DE. Equine Onchocerciasis. Aust Vet J. 1978; 54(11): 545, 2 ref.

21. Maizels RM, Balic AN, Gomez-Escobar MN, Taylor MD, Allen JE. Helminths parasites-masters of regulation. Immunol Rev. 2004 ; 201: 89-116.

22. Blood DC, Radositits. Veterinary medicine. A textbook of the diseases of cattle sheep, pigs, goats and horses. $7^{\text {th }}$ ed. Baillier, Tindall ; 1989.p.1065-1066.

23. Urquhart GM, Armour J, Duncan JL, Dunn AM, Jennings FW. Veterinary parasitology $2^{\text {nd }}$ ed. Blackwell Science, Oxford; 2003 P.93.

24. Abu-Elmagd MM Ahmed ZG. The occurrence of Setaria equina in donkeys eyes and their treatment. Assiut Vet Med J. 1994 ; 31 (62): 86-90.

25. Abu-Elmagd MM, Ahmed ZG, Michael SA. Treatment of Setaria equina infestation with ivermectin (22, 23-Dimydroavermectin B) under the Egyptian environmental conditions. Assiut Vet Med J. 1990; 23(45): 75-79.

26. Mukhopadhyay S, Dash AP, Ravindran B. Seteria digitata microfilariae in mastomys couths : an animal model for chemotherapeutic and immunobiological studies Parasitol. 1996 ; 113:323-330.

27. Sharma MC,Chinmay J. Serum mineral and haematobiochemical profile of microfilariae infected cattle in India :Its effects on production and therapy. Asian Aust J Anim Sci 2002;15(3):357-365.

28. Singh KS,Mukhopadhayay SK, Ganguly S Niyoyi D,Thiyaaseelan G, Ali I. Hematological and biochemical studies of Stephanofilarial dermatitis in infected cattle of West Bengal India Res Vet Sci 2011;91(2):194-195.

29. Goggin JM,Biller DS,Rost CM, De Bey BM Ludlow CL. Ultra sonographic identification of Dirofilaria immitis in the aorta and liver of a dog Am J Vet Med Asso.1997;210(11):1635-1637.

30. Sharma MC and Pachauri SP Blood cellular and biochemical studies in canine dirofilariasis Vet Res Comm.1982;5: 394-300. 